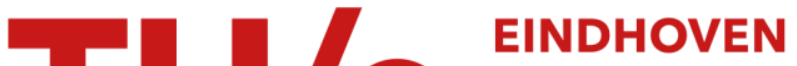 \\ UNIVERSITY OF \\ TECHNOLOGY
}

\section{Equipment for multifunctional use in high-performance capillary electrophoresis}

Citation for published version (APA):

Verheggen, T. P. E. M., \& Everaerts, F. M. (1993). Equipment for multifunctional use in high-performance capillary electrophoresis. Journal of Chromatography, 638(2), 147-153. https://doi.org/10.1016/00219673(93)83423-P

DOI:

10.1016/0021-9673(93)83423-P

Document status and date:

Published: 01/01/1993

\section{Document Version:}

Publisher's PDF, also known as Version of Record (includes final page, issue and volume numbers)

\section{Please check the document version of this publication:}

- A submitted manuscript is the version of the article upon submission and before peer-review. There can be important differences between the submitted version and the official published version of record. People interested in the research are advised to contact the author for the final version of the publication, or visit the $\mathrm{DOI}$ to the publisher's website.

- The final author version and the galley proof are versions of the publication after peer review.

- The final published version features the final layout of the paper including the volume, issue and page numbers.

Link to publication

\section{General rights}

Copyright and moral rights for the publications made accessible in the public portal are retained by the authors and/or other copyright owners and it is a condition of accessing publications that users recognise and abide by the legal requirements associated with these rights.

- Users may download and print one copy of any publication from the public portal for the purpose of private study or research.

- You may not further distribute the material or use it for any profit-making activity or commercial gain

- You may freely distribute the URL identifying the publication in the public portal.

If the publication is distributed under the terms of Article 25fa of the Dutch Copyright Act, indicated by the "Taverne" license above, please follow below link for the End User Agreement:

www.tue.nl/taverne

Take down policy

If you believe that this document breaches copyright please contact us at:

openaccess@tue.nl

providing details and we will investigate your claim. 


\title{
Equipment for multifunctional use in high-performance capillary electrophoresis
}

\author{
Theo P.E.M. Verheggen* and Frans M. Everaerts \\ Laboratory of Instrumental Analysis, Eindhoven University of Technology, P.O. Box 513, 5600 MB Eindhoven (Netherlands)
}

\begin{abstract}
Instrumental aspects of capillary electrophoresis are reported. The instrument discussed can operate in the "open" and "closed" modes. All kinds of capillaries and capillary diameters can be applied. With this apparatus it is possible to perform analysis in free solutions, such as zone electrophoresis, isotachophoresis and isoelectric focusing. Gel-filled columns can also be used and systems making use of micellar electrokinetic chromatography. Several examples of separations of mixtures of organic acids in the open and closed modes are given. A separation of DNA restriction digest in a gel-filled column in the open and closed modes is described. A rapid analysis in an open system of guanine from mites in house dust is reported.
\end{abstract}

\section{INTRODUCTION}

Because of its high efficiency, high-performance capillary electrophoresis (HPCE), which. includes various modes of capillary electrophoresis, is widely used in various fields. Sometimes electroosmotic plug flow (EOF) is suppressed $[1,2]$ and in some experiments EOF is used as a pumping mechanism [3]. A reduction of EOF can lead to an improvement in the resolution of the sample components.

For analytical separation techniques, the results obtained must be reproducible and repeatable. The influence of operating parameters on the reproducibility in capillary electrophoresis has been discussed by Foret and Boček [4].

When liquid levels in the buffer reservoirs at the capillary ends are unequal, hydrostatic flow (HF) results. The HF is parabolic in nature and therefore HF can contribute to zone broadening, making the experimental efficiency less than the

\footnotetext{
* Corresponding author.
}

theoretical value. This was extensively described by Grushka [5]. In isotachophoretic (ITP) analyses, the EOF is not constant in all zones, but commonly increases in the direction of the terminating zone [2]. This effect increases the turbulence of the liquid in each zone, while still an overall EOF is obtained.

In a study by Ackermans et al. [6], problems in quantitative analysis in open systems using ITP were discussed. In 1990, Verheggen et al. [7] investigated the reproducibility of migration times of serum components in a completely closed instrument by HPCE. A relative standard deviation of $0.7 \%$ was obtained. The instrument was limited to $0.2 \mathrm{~mm}$ PTFE capillaries and operated in the "closed" mode.

In this paper, it is shown that the HF can be blocked by membrane and simultaneously the EOF can be suppressed by additives. It is also possible to bypass the membrane, so that the EOF plays a role in the separation. Also, all kinds of capillaries and capillary diameters can easily be inserted. The construction of the electrode block [8], especially constructed for these analyses, and the first test results are given. 


\section{EXPERIMENTAL}

\section{Zone electrophoresis}

The equipment used is described in detail under Results and Discussion. Separation capillaries (100 and $50 \mu \mathrm{m}$ I.D.) made of fused silica (Siemens, Mühlheim, Germany) and PTFE capillaries (200 $\mu \mathrm{m}$ I.D., $350 \mu \mathrm{m}$ O.D.) (Habia, Breda, Netherlands) were used. Flat cellulose polyacetate membranes were used in the electrode compartment. A Spectra 100 variablewavelength UV absorbance detector was used (Spectra-Physics, San Jose, CA, USA). The power supply (type $\mathrm{HCN} 35-500$ ) was obtained from FUG Electronik (Rosenheim, Germany).

\section{Data acquisition}

The software used was the Caesar program (B *Wise, Geleen, Netherlands) running on an Olivetti M250 computer. As the interface a multilab (TUE-TS, Eindhoven Technical University) was applied.

\section{Chemicals}

The components of the test mixture, the buffer constituents and cetyltrimethylammonium bromide (CTAB), all of analytical-reagent grade, were purchased from Merck (Darmstadt, Germany). Mowiol poly(vinyl alcohol) (PVA) was supplied by Hoechst (Frankfurt, Germany). Ultra-pure water was used to prepare the buffers and all buffer and sample solutions were filtered through a $0.45-\mu \mathrm{m}$ filter.

\section{RESULTS AND DISCUSSION}

The basic unit is shown schematically in Fig. 1. The separation capillary $C$ is mounted between the electrode compartment $A$ and the vessel $B$. The capillary is surrounded by PTFE tubing used for cooling by forced air. The electrode compartment $A$ is composed of two blocks: the electrode vessel (1) with the earth electrode (2) and block (3), which has a channel through which the system can be rinsed and filled with electrolyte, using valves $4 \mathrm{a}$ and $4 \mathrm{~b}$. The capillary is introduced at one end through a septum (5) in the channel of block 3. A steel needle is mounted in the septum holder (7). By manual pressure on

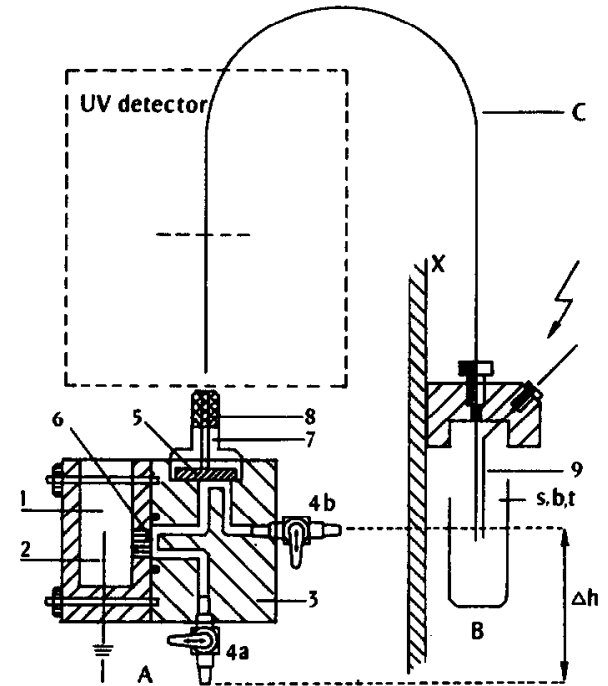

Fig. 1. Schematic diagram of electrophoretic equipment used for capillary electrophoresis (open/closed modes). $\mathbf{A}=$ Electrode compartment; B = vessel [buffer (b), samples (s), terminator $(\mathrm{t})] ; \mathrm{C}=$ separation capillary; $\mathrm{X}=$ support; $\mathbf{1}=$ electrode vessel; 2 = earth electrode; $3=$ block with channel; $4 \mathrm{a}$ and $\mathrm{b}=$ valves; $5=$ septum; $6=$ membrane; $7=$ septum holder; $8=$ knob with steel needle; $9=$ high-voltage electrode.

knob 8 , the needle will penetrate the channel through the septum. In this way it is easy to insert all kinds of capillaries and capillary diameters. After the introduction of the capillary into the channel, the needle is retracted and remains on top of the septum (5).

The channel in block 3 connects the electrode vessel (1) with the capillary $C$. Between the electrode vessel (1) and the block (3), a flat semi-permeable membrane (6) is clamped with two screws and an O-ring [2]. This means that the capillary is closed at one end by this membrane. Any gas produced at the electrode (2) will not affect the analysis. Liquid applied through valves $4 a$ and $4 b$ will pass and rinse the membrane. The volume of the channel in block 3 is large compared with that of the separation compartment. The potential drop in this channel, over and near the membrane, is small for the same reason. Therefore, it takes a long time before $\mathrm{pH}$ jumps, entering the capillary through the membrane, will reach the detector and thus influence the analyses [9].

Tiny movements of the membrane will affect 
the reproducibility of the injection and migration times, hence the membrane surface area is limited by three narrow channels of $0.5 \mathrm{~mm}$ diameter connecting the electrode vessel (1) with the capillary $C$. The electrode vessel is filled with ultra-pure water, to prevent the formation of any compounds by electrode reactions. On the other side of the capillary, vessel $B$ and a high-voltage electrode (9) are situated. The vessel can easily be replaced in a vertical direction at any position along the support $X$, which is used for variable gravity injection [10].

Via valve $4 a$ the channel in the block and the capillary $C$ can be filled with buffer. For the introduction of the sample, the entrance of the capillary is dipped into the sample vessel(s). By opening valve $4 \mathrm{a}$ for a fixed time, the sample is introduced by gravity flow, where $\Delta h$ is the driving force. After changing the sample vessel with either buffer (b) or terminating vessel ( $t$ ), the system can be operated in any HPCE mode. When both valves $4 a$ and $4 b$ are closed, a closed system is obtained. By opening valve $4 \mathrm{~b}$, an open system utilizing the electroosmotic flow is created. In the latter instance, it is of great importance, of course, that the liquid level in the buffer vessel is at the same height as the outlet of valve $4 \mathrm{~b}$.

To test the equipment, non-coated fused-silica and PTFE capillaries were used. The reproducibility of migration times was tested in a system of $\beta$-alanine $(0.05 M)$-acetate $(\mathrm{pH} \mathrm{3.8)}$ using an anionic test mixture. The sample consisted of potassium dichromate, pyrazine-2,3-dicarboxylate, pyrazole-3,5-dicarboxylate, orotate, sulphanilate, dihydroxy-2,4-benzoate, 4-nitrobenzoate, hippurate, 2,4,6-trimethoxybenzoate and benzoate. The separation compartment was a $100-\mu \mathrm{m}$ fused-silica capillary with an effective length of $44 \mathrm{~cm}$.

Injection was made by gravity flow, with $\Delta h=$ $5 \mathrm{~cm}$ and an injection time of $15 \mathrm{~s}$. The voltage used was $20 \mathrm{kV}$. The analysis was carried out in the closed mode.

Fig. 2 shows the separation of the anion test mixture. Note that no additives are used in the electrolyte. At low pH the EOF is small and does not influence the separation. In Table I the test mixture composition, the migration times,

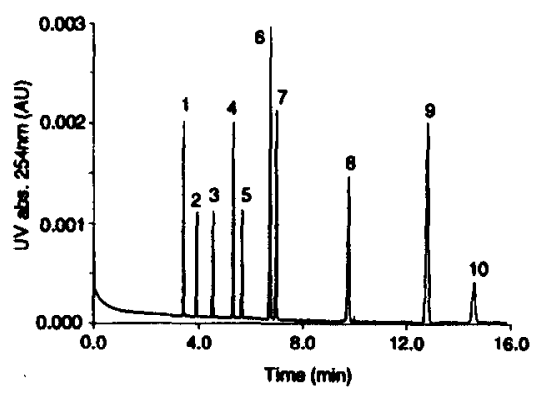

Fig. 2. Zone electropherogram of a test mixture of anions at pH 3.8 (closed mode). For peak numbers, see Table I. Further details are given in the text.

R.S.D. $(n=6)$ of the migration times and plate numbers are given. High plate numbers are obtained, which means that the EOF is small. In the closed system the hydrodynamic flow is blocked by the membrane, but the EOF still takes place at the capillary wall surface and is compensated for by the EOF counterflow along the capillary axis. This leads to disturbances of the zones $[2,4,11]$.

The $\zeta$-potential of the untreated capillary wall increases with increase in $\mathrm{pH}$. An experiment at higher $\mathrm{pH}$ will illustrate this. The system used was Tris $(0.02 M)$-phosphoric acid ( $\mathrm{pH} 7)$. The same capillary diameter, length and voltage were

\section{TABLE I}

AVERAGE VALUES $(n=6)$ AND RELATIVE STANDARD DEVIATIONS (R.S.D.) OF THE MIGRATION TIMES, $t$, AND PLATE NUMBERS $(N)$ IN CZE (CLOSED MODE)

Effective length of the capillary (100 $\mu \mathrm{m}$ I.D.), $44 \mathrm{~cm}$; system $\mathrm{pH}, 3.8$; voltage, $20 \mathrm{kV}$.

\begin{tabular}{llrlr}
\hline No. & Component & $\begin{array}{l}t_{\text {av }} \\
(\mathrm{min})\end{array}$ & $\begin{array}{l}\text { R.S.D. } \\
(\%)\end{array}$ & $N$ \\
\hline 1 & Potassium dichromate & 3.42 & 0.80 & 82000 \\
2 & Pyrazine-2,3-dicarboxylate & 3.95 & 0.80 & 118000 \\
3 & Pyrazole-3,5-dicarboxylate & 4.59 & 0.84 & 141000 \\
4 & Orotate & 5.36 & 0.90 & 192000 \\
5 & Sulphanilate & 5.71 & 1.11 & 193000 \\
6 & Dihydroxy-2,4-benzoate & 6.78 & 1.03 & 165000 \\
7 & 4-Nitrobenzoate & 7.02 & 0.99 & 159000 \\
8 & Hippurate & 9.80 & 1.05 & 118000 \\
9 & 2,4,6-Trimethoxybenzoate & 12.82 & 1.02 & 91000 \\
10 & Benzoate & 14.36 & 1.10 & 71000 \\
\hline
\end{tabular}


used. The capillary was rinsed with $0.1 \mathrm{M} \mathrm{HCl}$, $0.1 \mathrm{M} \mathrm{KOH}$ and water. The sample consisted of chromate, pyrazine 2,3-dicarboxylate, sulphanilate, orotate, urate, hippurate and $o$-iodohippurate. In Fig. 3a the separation is shown of the seven components in the closed mode. The separation is unsatisfactory owing to EOF disturbance. Cetyltrimethylammonium bromide (CTAB) is known to decrease and even change the sign of the $\zeta$-potential of the capillary wall [12]. By adding a small concentration $\left(1 \cdot 10^{-4}\right.$ $M$ ) of CTAB, the $\zeta$-potential of the capillary wall was decreased, but the results did not improve (see Fig. 3b).

For the next separation, the capillary was

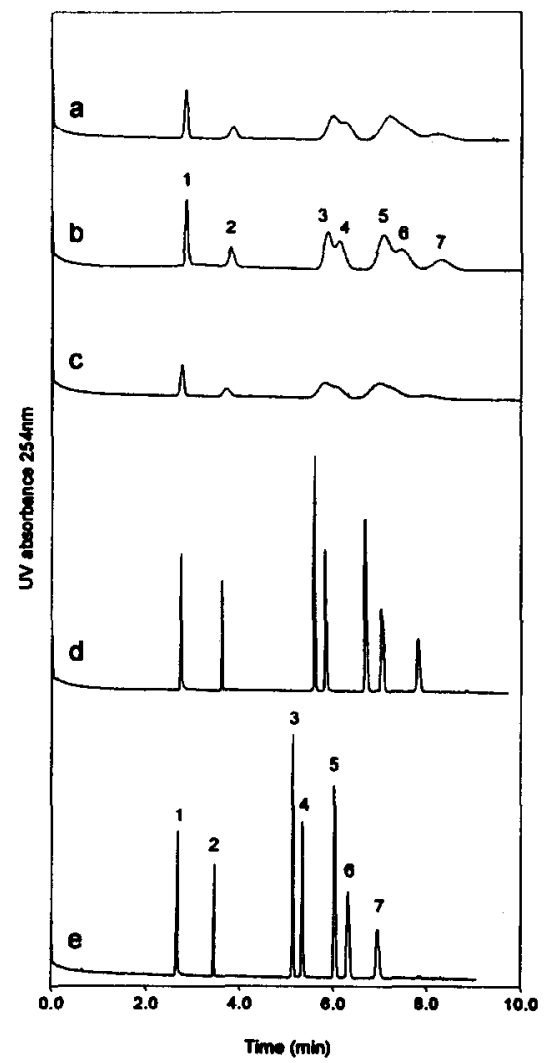

Fig. 3. Zone electropherograms of a test mixture of anions at pH 7. For peak numbers, see Table II. (a) No additives in the electrolyte (closed mode); (b) electrolyte with $1 \cdot 10^{-4} M$ CTAB (closed mode); (c) electrolyte with $0.05 \%$ PVA (closed mode); (d) electrolyte with $0.5 \cdot 10^{-4} M$ CTAB $+0.025 \%$ PVA (closed mode); (e) electrolyte as in (d) (open mode). The height of peak 3 is 0.004 absorbance units. The same gain was used for all analyses. extensively rinsed with water. PVA $(0.05 \%)$ was added to the standard electrolyte. This will also decrease the $\zeta$-potential of the capillary wall and, in addition, it may increase the liquid viscosity at the capillary wall. There was also no improvement (see Fig. 3c). The combination of both $0.5 \cdot 10^{-4} M$ CTAB and $0.025 \%$ PVA gives excellent results in the closed mode, as shown in Fig. 3d. In the open mode (Fig. 3e) excellent results were also obtained. This effect of the combination of these two constituents is not clear, and is still under investigation. The migration times between the two analyses are different. In this instance the migration times of the components in the open system are faster, because the EOF is in the same direction as the electrophoretic velocity of the separands. This means that $\zeta$-potential of the capillary wall has changed polarity and is now slightly positive owing to the addition of CTAB. The EOF direction follows from the comparison between the two analyses in the open and closed modes. In Table II the test mixture composition and the average plate numbers in the open and closed modes are given for the analyses in Fig. 3d and $\mathrm{e}$.

By observing the outlet of valve $4 \mathrm{~b}$ (see Fig. 1) in the electrode block during analyses in the open mode, it can be seen directly if the EOF is near zero or the direction in which the liquid flows. For a closed system, slightly suppressing EOF gives a sufficient separation. In Fig. 4 an

\section{TABLE II}

AVERAGE PLATE NUMBERS $(n=6)$ OBTAINED WITH THE OPEN AND CLOSED SYSTEM

Effective length of the capillary (100 $\mu \mathrm{m}$ I.D.), $44 \mathrm{~cm}$; system, pH 7; voltage, $20 \mathrm{kV}$.

\begin{tabular}{llrr}
\hline No. & Component & Closed & \multicolumn{1}{c}{ Open } \\
\hline 1 & Chromate & 71000 & 66000 \\
2 & Pyrazine-2,3-dicarboxylate & 262000 & 241000 \\
3 & Sulphanilate & 227000 & 216000 \\
4 & Orotate & 165000 & 158000 \\
5 & Urate & 108000 & 106000 \\
6 & Hippurate & 68000 & 62000 \\
7 & o-Iodohippurate & 86000 & 67000 \\
\hline
\end{tabular}


analysis is shown of the same standard mixture (Table II), where the EOF was higher but not in the "reversed" mode. The system used was Tris $(0.02 M)$-phosphoric acid (pH 7). In Fig. 4a, the separation of the anions is shown in the closed mode. The full analysis of the seven components is completed in $10 \mathrm{~min}$. The peaks are not so sharp owing to the EOF disturbance. In Fig. 4b, the results of the analysis in the open mode are given. In the same analysis time $(10 \mathrm{~min})$ only three components are detected owing to the EOF counterflow. The migration order in both analyses remains similar.

In the next experiment, the separation was effected in an open system, where the EOF is not suppressed, but optimized. A similar length and diameter of the capillary were used. Again the test mixture of anions mentioned above was separated at $\mathrm{pH} 7$. The high positive voltage was at the injection side.

In Fig. 5a, after the EOF marker (mesityl oxide) slowly migrating anions are detected first. Ions that are too fast, with respect to the EOF, will not reach the detector. In the analysis in Fig. $5 \mathrm{~b}$, the migration order is reversed by changing the polarity at the electrodes. The analysis was
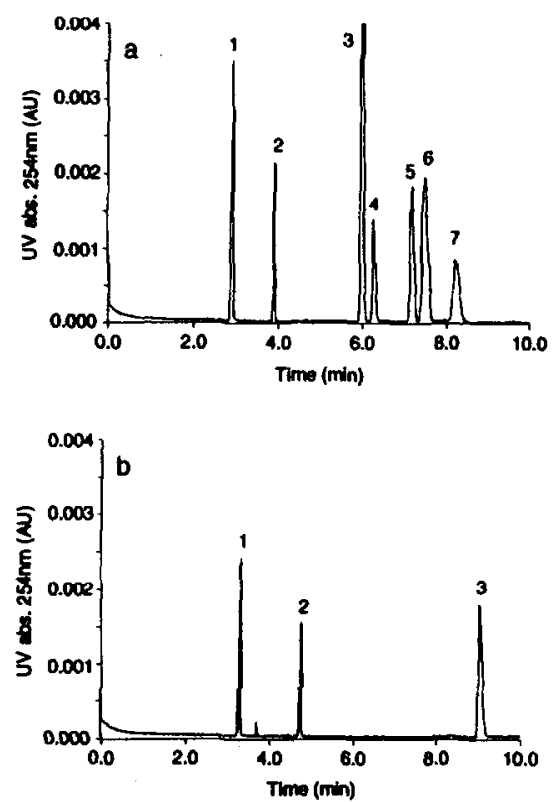

Fig. 4. Zone electropherogram of a test mixture of anions at pH 7. For peak numbers, see Table II. (a) Closed mode; (b) open mode.
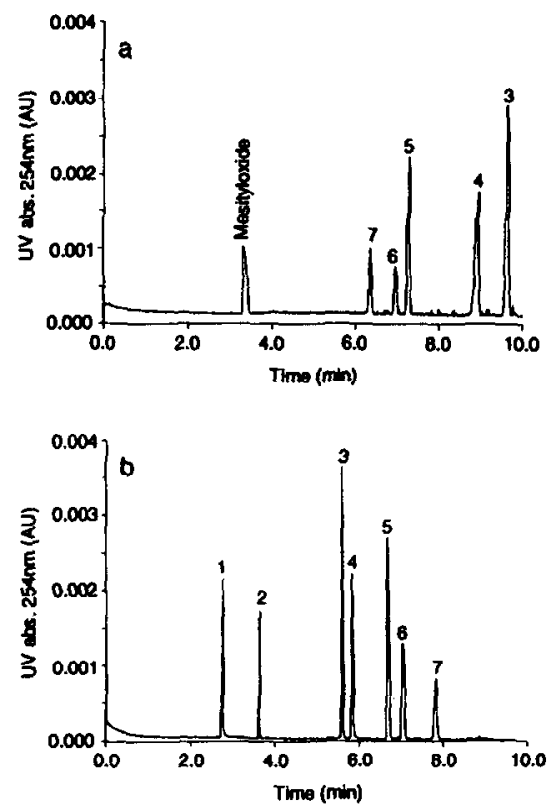

Fig. 5. Zone electropherogram of a text mixture of anions at pH 7. For peak numbers, see Table II. (a) Open mode; (b) closed mode and reversed polarity. For further details, see text.

made in the closed mode. The buffer contained CTAB and PVA as additives. All seven components are detected. From these analyses (Fig. $5 a$ and $b$ ) we can conclude that in the closed mode, suppressing the EOF and hydrodynamic flow, the analysis is faster, the resolution is better and the plate numbers are higher.

In the next experiment a PTFE capillary was used (200 $\mu \mathrm{m}$ I.D. and $350 \mu \mathrm{m}$ O.D.). The electrolyte system was $\beta$-alanine $(0.01 M)$-acetate $(\mathrm{pH} 3.8)$. The separands were potassium dichromate, pyrazole-3,5-dicarboxylate, orotate, sulphanilate, dihydroxy-2,4-benzoate, 4-nitrobenzoate and hippurate. The buffer contained no additive. The separation, performed in the closed mode, is shown in Fig. 6. Even in PTFE capillaries wavelengths down to $200 \mathrm{~nm}$ can be used successfully [13]. Here variable-wavelength detection shows in addition the sensitivity-selectivity trade-off.

One of the HPCE modes, ITP, is not discussed in this paper. It will be evident from the preceding description that ITP can also be performed with the instrument uscd. ITP in the closed mode using capillaries down to $50 \mu \mathrm{m}$ I.D. is 


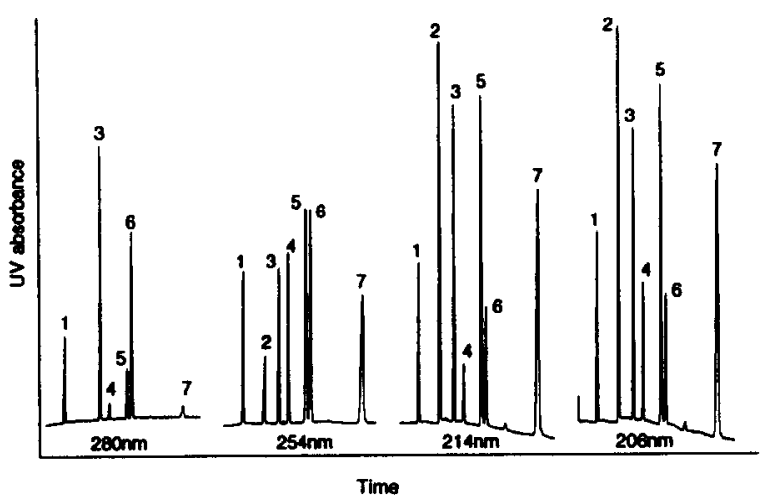

Fig. 6. Zone electropherograms of a text mixture at $\mathrm{pH} 3.8$ in a PTFE capillary at different wavelengths. $1=$ Potassium dichromate; 2 = pyrazole-3,5-dicarboxylate; $3=$ orotate; $4=$ sulphanilate; $5=$ dihydroxy-2,4-benzoate; $6=4$-nitrobenzoate; $7=$ hippurate. The detector attenuation was the same for all analyses.

now within reach, with the restriction that as yet there is no universal conductivity detector available for the present prototype. This would decrease the minimum zone volume that can be determined by a considerable factor.

\section{Application}

A gel-filled column was mounted in the same modular equipment. DNA restriction fragments [14] were analysed in the open and closed modes. A fused-silica capillary of $100 \mu \mathrm{m}$ with an effective length of $30 \mathrm{~cm}$ and total length of $40 \mathrm{~cm}$ was used. The buffer contained $0.1 \mathrm{M}$ Tris-acetate and $2 \mathrm{mM}$ EDTA (pH 8.3). Electromigration was used for sample introduction $(10 \mathrm{~s}, 2 \mathrm{kV})$. The separation voltage used was 5 $k V$. A sample of $\phi X-174$ RF DNA Hae III was

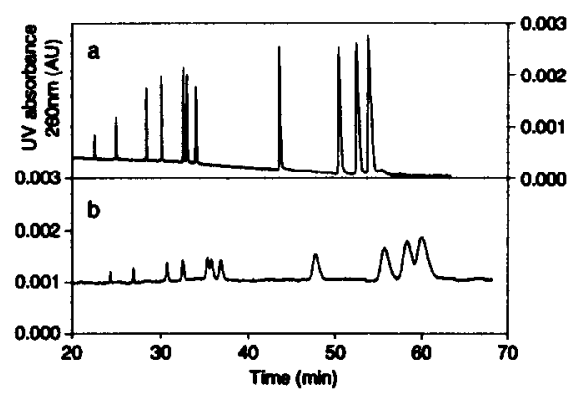

Fig. 7. Zone electropherogram of DNA restriction fragments in a gel-filled capillary. (a) Open mode; (b) closed mode (UV detection at $260 \mathrm{~nm}$ ). For further details, see text.

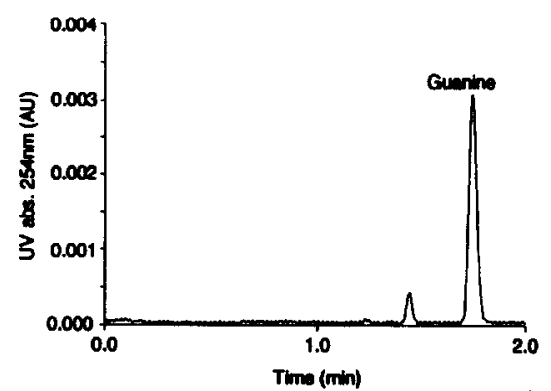

Fig. 8. Zone electropherogram of guanine in a sample of house dust mite (open mode). For further details, see text.

analysed. Comparison of the open and closed modes shows that there is a difference in the efficiency (see Fig. 7a and b). This subject is under investigation.

A Danish study [15] revealed that $60 \%$ of asthma cases are due to excretion of allergenic compounds by house dust mites in homes. The guanine (2-amino-6-hydroxypurine) content proved to be a reliable indicator [16]. The HPCE method introduced is superior to the HPLC method [17] (time, variable costs) and more accurate than the commercial Acarex test. The HPLC sample pretreatment procedure [17] was slightly modified and used for HPCE. In the HPCE determination, guanine was measured as a cation in the system glycine $(0.01 M)$-tartrate (pH 3). Determination as an anion at higher $\mathrm{pH}$ was unsatisfactory owing to the lower selectivity. The separation compartment was a $50-\mu \mathrm{m}$ fusedsilica capillary with an effective length of $\mathbf{2 6 . 5}$ $\mathrm{cm}$. The voltage used was $30 \mathrm{kV}$. Analysis for 2 min gave a more than sufficient resolution of guanine, so that a shorter capillary would have been sufficient (see Fig. 8).

\section{CONCLUSIONS}

The equipment presented facilitates the evaluation of experimental conditions in any HPCE mode in a flexible manner. By comparing analyses in the open and closed modes, the effect of EOF on migration can be determined more readily, also in systems where EOF is suppressed by additives, coating the capillary or in gel columns. A number of phenomena observed can thus be investigated further. In addition, when 
sample matrix effects on migration are suspected, dual analyses in both modes will yield decisive information.

The equipment is in principle suitable for automation and can be extended with a commercial autoinjector. As in almost all analytical separation techniques, especially in HPCE, a wide choice of capillary diameters and lengths makes it easy to optimize applications in terms of efficiency and detection selectivity. For all basic HPCE techniques, configurations can easily be selected to achieve such an optimum without changing the equipment used.

\section{ACKNOWLEDGEMENT}

J.C. Reijenga is thanked for helpful discussions.

\section{REFERENCES}

1 A.J.P. Martin and F.M. Everaerts, Proc. R. Soc. London, Ser. A, 316 (1970) 493.

2 F.M. Everaerts, J.L. Beckers and Th.P.E.M. Verheggen, Isotachophoresis: Theory, Instrumentation and Applications, Elsevier, Amsterdam, 1976.
3 J.W. Jorgenson and K.D. Lukacs, J. Chromatogr., 218 (1981) 209.

4 F. Foret and P. Boček, in A. Chrambach, M.J. Dunn and B.J. Radola (Editors), Capillary Electrophoresis (Advances in Electrophoresis, Vol. 3), VCH, Weinheim, 1989, pp. 273-342.

5 E. Grushka, J. Chromatogr, 559 (1991) 81.

6 M.T. Ackermans, F.M. Everaerts and J.L. Beckers, J. Chromatogr., 545 (1991) 283.

7 Th.P.E.M. Verheggen, A.C. Schoots and F.M. Everaerts, J. Chromatogr., 503 (1990) 245.

8 Th.P.E.M. Verheggen, Final Report: Capillary Electrophoretic Diagnostic Unit, BIOLAB Workstation; Phase A2, July 1991, Comprimo Consulting Services, Amsterdam, 1991.

9 F.M. Everaerts, J. Vacik, Th.P.E.M. Verheggen and J. Zuska, J. Chromatogr., 49 (1970) 262.

10 T. Tsuda, K. Nomura and G. Nakagawa, J. Chromatogr., 264 (1983) 385.

11 R. Virtanen, Acta Polytech. Scand., 123 (1974) 1.

12 J.C. Reijenga, G. Aben, Th.P.E.M. Verheggen and F.M. Everaerts, J. Chromatogr., 260 (1983) 241.

13 Th.P.E.M. Verheggen, F.M. Everaerts and J.C. Reijenga, J. Chromatogr., 320 (1985) 99.

14 M.J. van der Schans, Graduation Report, University of Technology, Eindhoven, 1992.

15 J. Korsgaard, Am. Rev. Respir. Dis., 128 (1983) 231.

16 J.E.M.H. van Bronswijk, E. Bischoff, W. Schirmacher and F.M. Kniest, J. Med. Entomol., 26 (1989) 55.

17 E.R.C. Bischoff, F.M. Kniest and W. Schirmacher, Environ. Technol., 13 (1992) 377. 